\title{
Experience of safety monitoring equipment application in the production processes of coal mines in Ukraine
}

\author{
Valeriy Lopatin \\ National Academy of Sciences of Ukraine, Ukraine \\ Bohdan Kopey \\ Ivano-Frankivsk National Technical University \\ of Oil and Gas, Ukraine
}

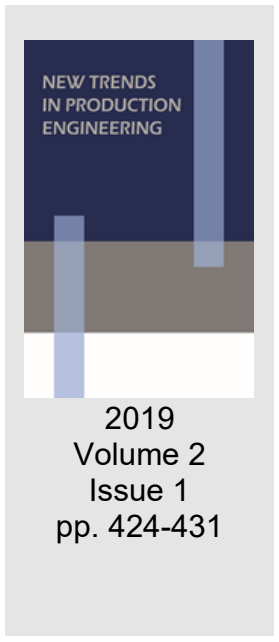

Date of submission to the Editor: 05/2019

Date of acceptance by the Editor: 08/2019

\section{INTRODUCTION}

At present, there are about one and a half hundred coal mines in Ukraine (together with a significant part of coal-mining enterprises located in the occupied territory), of which $2 / 3$ belong to the 1 st category with an increased risk of methane explosion, a third are dangerous due to coal dust explosions. According to the State Labor Protection Authority of Ukraine, coal mining in mines is carried out in extremely difficult mining and geological and temperature conditions. For example, March 4, 2015, during the occupation, at the mine named Zasyadko (Fig. 1) methane exploded at a depth of 1230 meters. 34 people died.

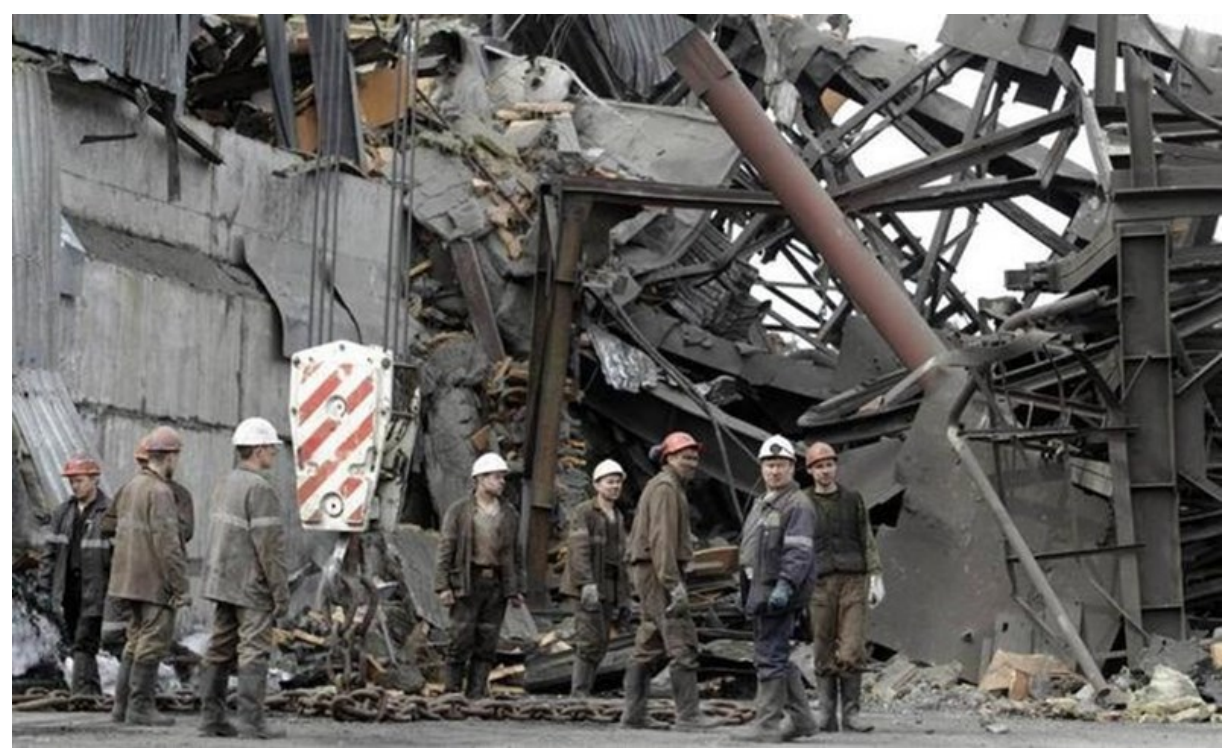

Fig.1 Accident after the explosion at the mine named Zasyadko

Due to the explosion, some of the important paths of the Zasyadko mine were collapsed. 50 people were underground, two passages and one mining site were 
damaged. During the years of independence of Ukraine, less than a dozen coal mines (approximately 5\%) were actually reconstructed, despite the fact that the average coal mining depth is already about $900 \mathrm{~m}$. Coal mining is carried out on horizons up to 1,400 meters at two dozen mines. In Ukraine, about twenty coal mining companies and almost $2 / 3$ are privately owned. For this reason, the majority of Ukrainian coal-mining enterprises have not performed the necessary repairs for years, and the miners are still working with old worn-out equipment, which are the main causes of new explosions, landslides and death of miners. The private property of Ukrainian coal-mining enterprises makes state control over them virtually impossible and in fact excludes even the possibility of their closure. Ukrainian legislation, departmental by-laws and law enforcement agencies, as a rule, are on the side of the owner of Ukrainian coal mining enterprises. According to Art. 38 of the Law of Ukraine on Labor Protection, state supervision over compliance with legislative and other acts is carried out only by officials specially authorized by the State Industrial Supervision Authority of Ukraine, who have the right to freely visit the controlled enterprises (objects) and carry out in the presence of the employer or his representative compliance with the legislation related to their competence. The main traumatic factors in the coal mines of Ukraine are: gas and dust explosions, the collapse of coal and roof rocks, the exploitation of underground transport. Currently, the Ministry of Energy and Coal Industry of Ukraine has decided to reconstruct only a part of the state coal mines.

\section{ANALYSIS OF RESEARCH AND PUBLICATIONS}

It should be noted that the problem of utilization of methane from coal mines is relevant throughout the world. For example, in 2013, at the International Conference on Industrial Safety and Methane Utilization in Geneva, the question was raised about creating a unified system of industrial safety analytics and methane utilization in the European Union. According to the research conducted, coal mining at the fields of Ukraine for the year is allocated from 1600 to 2500 million $\mathrm{m}^{2}$ of methane, and about $12 \%$ is actually utilized (Lost Space, 2011). For example, in the village of Glukhov, Sokalsky district, Lviv region, on March 2, 2017, a collapse of a rock was caused by an explosion (methane was exploded) at the mine number 10 "Stepnaya" of Lvivugol OJSC. At the time of the collapse after the explosion, 172 miners were in the Stepova mine, 34 miners were in the emergency area, of whom ten died and six more miners with injuries were lifted to the surface ( $\mathrm{Na}$ shakhte). It is known that December 1-2, 2007 at the mine to name Zasyadko, when in one of the sections a methane-air mixture exploded, 106 people were died. The following month, another 5 rescuers died there. Prior to this, even during two accidents, 50-55 miners died at the same time. Despite the deadly statistics (290 miners died, which accounts for $32 \%$ of all victims in the Ukrainian coal mines), the mine named Zasyadko is not going to close ( $\mathrm{Na}$ shakhte).

Most of the tragedies in coal mines are due to the human factor, when unpreparedness or untimely reaction of a miner to certain abnormal situations 
affects. It is believed that the coal industry has developed a difficult situation with staffing, there are not enough highly skilled workers, and often engineers and technicians are not able to fully solve the tasks assigned to it. Therefore, the causes of the death of miners by $70 \%$ lie in the inept organization of labor and in a poorly organized system of control of production processes (Sagan, 2012). Based on the seven-year statistics for the period 2007-2013 years Kryvyi Rig mining territorial management the number of injuries and accidents for organizational reasons is estimated at $70 \%$ in general, and at mining enterprises up to $90 \%$ (Zhelikhovskaya, 2014). The authors consider the assessment of Kryvyi Rig Mining Territorial Administration for organizational reasons as evidence-based and reliable. A similar opinion (up to $90 \%$ ) is shared by the specialists of the Donetsk Coal Research Institute named M.M. Fedorov (Gryadushchiy, 2012).

In such a situation, the adequacy and correct assessment of the accuracy of control of production processes at Ukrainian coal mines is of great state importance. In the Ukrainian coal mines, the following production process control systems have been introduced: seismic acoustic prediction equipment for mountain massifs, aerogas control equipment, integrated degassing equipment, automated control and management system for belt conveyors and a variety of others. There are many other domestic production process control systems for Ukrainian coal mining enterprises at various stages of development. Separately, we would like to mention the well-known unified telecommunications system of dispatching control and automated control of mining machines and technological complexes (UTAS). At the end of the last century, development of UTAS began at the Petrovsky Coal Machine-Building Plant (Donetsk) to ensure continuous monitoring and control of safe mining operations and the prevention of dangerous situations at the mine, and since 2004, they have mastered the production of the first UTAS systems. Currently, UTAS is installed in 37 mines in Donetsk, Lugansk, Lviv and Dnipropetrovsk regions (Sistema bezopasnosti UTAS). According to some estimates of the pilot operation of UTAS at coal mines in Ukraine, the reduction of the "Complex mine accident rate indicator" was confirmed by no less than $20 \%$ per year (Khokhotva, Shaytan, 2014).

\section{PRESENTATION OF THE MAIN MATERIAL AND RESEARCH RESULTS}

The main specificity of the mining industry is that technological processes, machines, machinery, equipment and other potentially hazardous products are allowed into operation (for use) only if they are examined for compliance with their regulatory and legal acts and industry standards of Ukraine (SOU) (clause 1 Article 20 of the Mining Law of Ukraine, No. 1127-XIV of 10/06/1999). In accordance with the laws of Ukraine, the employer bears direct personal responsibility (up to and including criminal) for violation of the specified requirements at its facility (Art. 13 of the Labor Code of Ukraine). The accident at the coal mine in Lviv in 2017 was the occasion to again raise the issue of the potential danger of coal mining enterprises in Ukraine. 
However, due to the change in the situation related to the occupation of a part of Donbass, scientific organizations and leading Ukrainian specialists in charge of security issues for coal mines remained in the occupied territory. Currently under the occupation were: Research Institute "Ugleautomatizatsiya", MakNII, Dongiprouglemash, NIIGD "Respirator", NIIGM named M.M. Fedorov, Avtomatgormash OJSC named after V.A. Antipov and many other leading organizations of the coal industry. This includes the Petrovsky Coal Engineering Plant, now the ITRAS Engineering Plant (Donetsk), the only manufacturer and supplier of UTAS systems for mines.

- The UTAS system is designed to provide integrated mine safety through:

- continuous monitoring of the parameters of machines, technological complexes and mine atmosphere of mine workings;

- automated control of mining machines and technological complexes based on the use of constantly processed and accumulated data on the state of mining equipment and the atmosphere of workings transmitted to the control room of the mine through telecommunications.

The UTAS system performs:

- collection and storage of data on the state of mining equipment, mine atmosphere in the mine workings, as well as information on pre-emergency and emergency situations;

- processing of the received information according to a predetermined algorithm and issuing alarm and emergency shutdown commands;

- data transfer to the dispatcher to the surface;

- processing, visualization and storage of the collected information on a previously developed algorithm;

- transfer of control commands from the dispatcher to underground facilities.

The UTAS system is an open two-level system with subsystems of the lower and upper levels, the communication between them is carried out through the RS485 serial interface via the fiber-optic lines of the mine (Fig. 2).

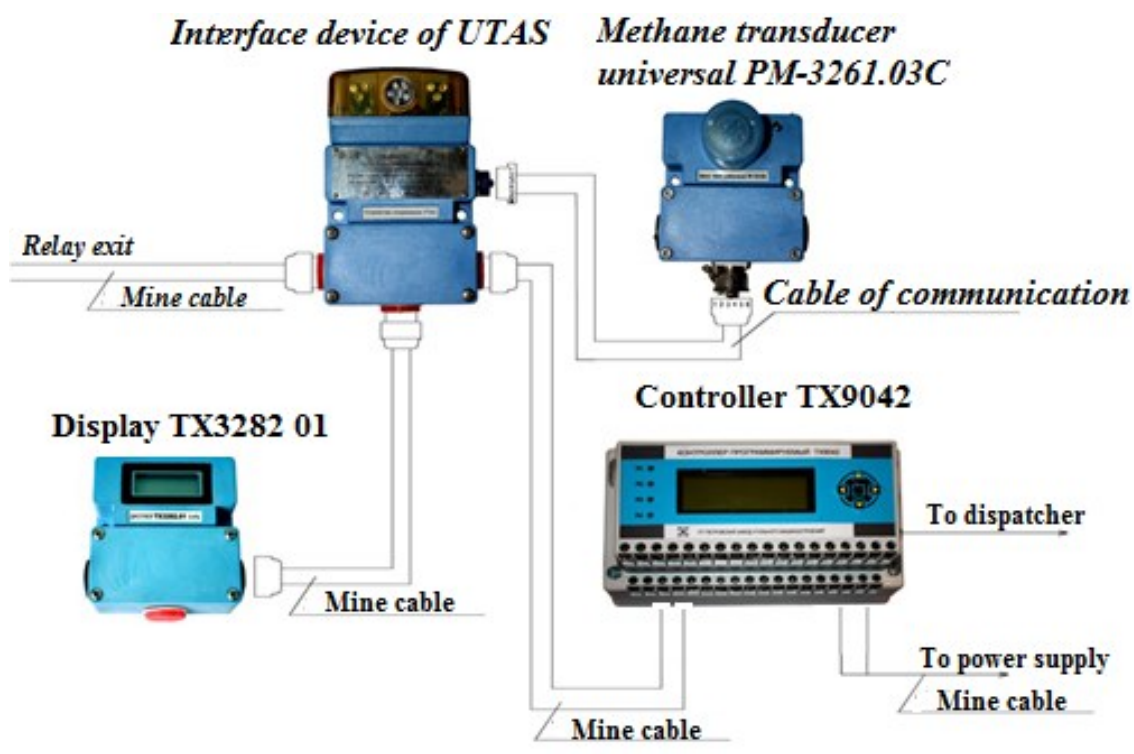

Fig. 2 Fragment of the UTAS system (methane control subsystem) 
The number and composition of subsystems of a particular UTAS system is determined by a special project for each coal mine. It is possible to expand the composition of subsystems due to the introduction of sensors and other devices, subject to agreement on technical parameters with UTAS devices.

UTAS and other equipment for monitoring the safety of production processes in coal mines is a typical real-time system (SRV), which must collect data of monitored parameters, process them in accordance with specified algorithms and issue the result of monitoring for such a period of time that ensures the successful solution of the stated problems. UTAS (SRV) - are synthesized by a flexible combination of relatively simple dissipative structures with definite ratios of continuous and discrete properties. At present, the SRV has been further developed, theoretical and practical study, so the author does not see any fundamental problems in resolving this issue.

The main features and difficulties of the technological processes of coal mines are problematic, and sometimes impossible to ensure direct contact of the sensitive element of the sensor with a controlled environment. This problem also has solutions.

According to the current laws of Ukraine, the equipment for monitoring the safety of production processes in coal mines is subject to sectoral (departmental) expertise for compliance with the MSK regulations of Ukraine and sectoral standards of Ukraine (SOU) with the approval and approval of sectoral (departmental) acceptance acts, regulatory documents of control in the Ministry of Industrial Policy Of Ukraine and the passage of the state metrological certification in the State Standards of Ukraine. This is required by clause 7 of the "List of facilities, machines, mechanisms, equipment of increased danger", Appendix 2 to the Resolution of the Cabinet of Ministers of Ukraine No. 1631 dated October 15, 2003. For example, the UTAS system has passed complex certification tests, it has two permits of the State Industrial Supervision Authority (No. 3216.30.07-29.52.1 of 09.11.2007 and for "emergency shutdown" No. 2461.30.09-29.52.1 of 20.08.2009).

Of course, UTAS is a qualitatively new step forward and its advantage is that it allows you to recognize and predict the possibility of emergency situations in the initial stages, solves the problem of increasing the level of safety comprehensively and fully for the entire technological cycle. For example, only in 2013, the UTAS system installed at the Shakhtyorsk-Glubokaya mine eliminated more than a dozen emergency situations. For example, with the help of the UTAS system at the Shcheglovskaya-Glubokaya mine, the real cause of the incident was almost immediately established - the demolition man performed an unauthorized blasting, did not report where he was, even the shift supervisor - in a short time managed to minimize losses. There are many more examples of the effective and efficient use of UTAS and other equipment for monitoring the safety of production processes in coal mines in Ukraine.

At the mine number 10 "Stepna" of OJSC "Lvivugol" the state commission accepted UTAS for operation back in 2014 , at the time of the above-mentioned accident in 2017 it was in operation for three years. According to the Chairman 
of the State Industrial Supervision of Ukraine, the complete debugging of the technology of the UTAS system and its fine-tuning at the coal mine is one and a half to two years (Khokhotva, 2014).

Thus, it was revealed that the safety technology envisaged by the UTAS developer was completely worked out, the system was finally brought to technical operation at a specific coal mine, and the technical staff serving UTAS had sufficient operational experience of this system. However, it was unable to completely eliminate the accident.

The authors see the following explanation of the situation. It is known that the increase in the level of safety is achieved due to: favorable mining and geological conditions, a high technical level of mining equipment in terms of productivity, reliability, service life and safety of operation of mining equipment and provision of integrated mine safety through equipment monitoring the production processes of coal mines.

If we take as a criterion of safety an indicator of the ratio of the recorded cases of violations per thousand tons of coal mined, then the situation is as follows.

As can be seen (Fig. 3), in no country in the world has "absolute security" been achieved in coal mines, i.e. the concept of "absolute security", in which the possibility of injuries and accidents is completely excluded, cannot be realized. The authors have already expressed his point of view on the need to move from the concept of "absolute security" to an acceptable risk (Lopatin, 2017, Nos, 2012).

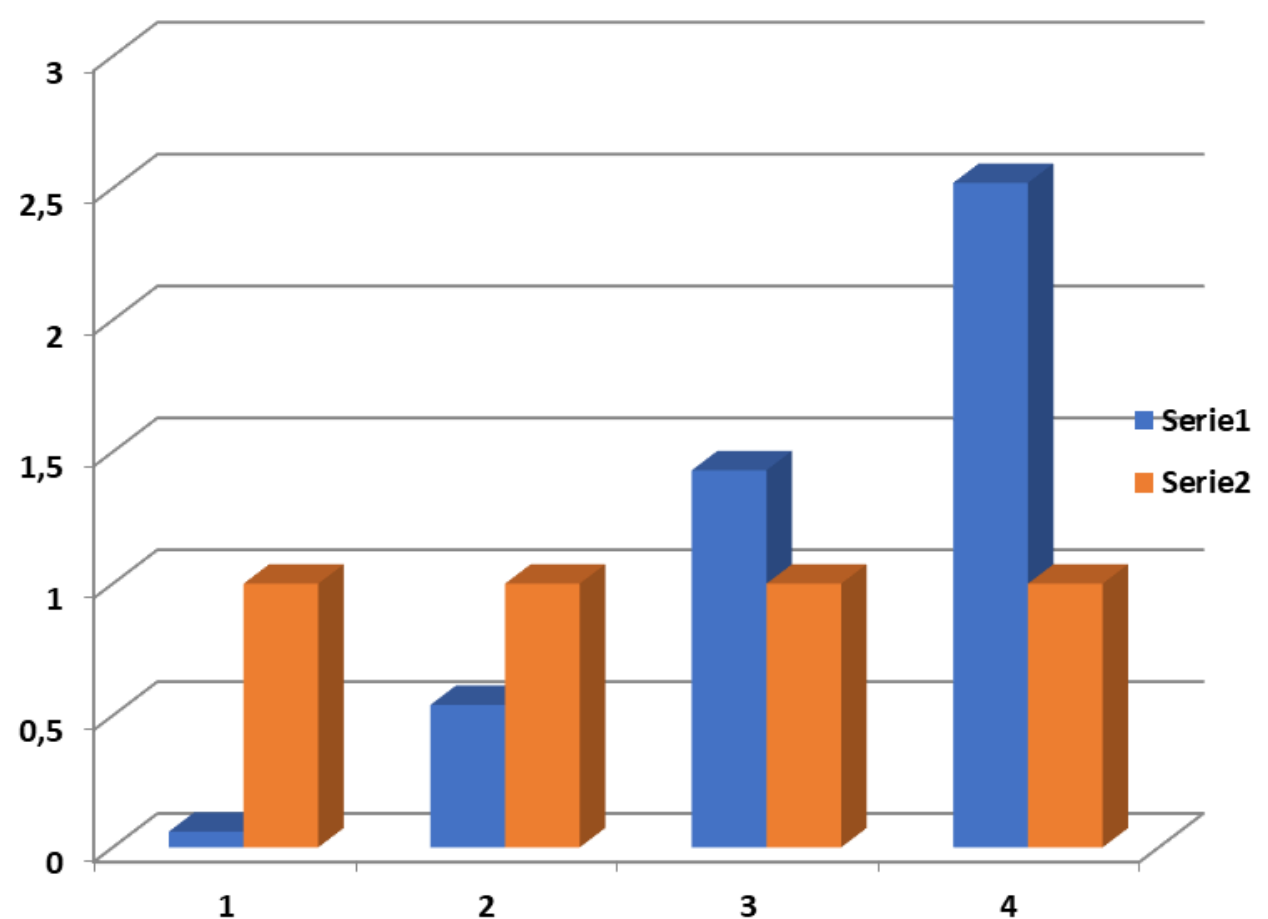

Fig. 3 Safety diagram in terms of reported violations per thousand tons of coal mined, where: 1 - United States, 2 - Germany, 3 - Russian Federation, 4 - Ukraine

For example, in 1979, the Federal Constitutional Court of Germany came to the conclusion that the requirement of absolute security leads to ignoring the limits of human knowledge and to the prohibition of any use of technology (Nos, 2012). 
The concept of "absolute security" applied to the 70s of the EU countries was replaced by an acceptable risk. In the US, these issues began to be dealt with even earlier, with sufficient funding, and the results of the work are clear (Fig. $3)$. This concept is being introduced in recent years in the Russian Federation. Unfortunately, Ukraine is more conservative and still lags behind, although there are successes in this direction. For example, the standard DSTU OHSAS 18001: 2010 was introduced from 01/01/2011.

Of course, the UTAS, which was created two decades ago, was built on the old concept of "absolute security". Moreover, it concerns the entire equipment for monitoring the safety of the production processes of coal mines of earlier development.

As is clear from the above, it is impossible to quickly and cheaply create equipment for monitoring the safety of the production processes of coal mines. The equipment for controlling the safety of coal mine production processes is a very expensive pleasure. For example, if we assume that the cost of UTAS is 20 million hrn, and it reduces the "Complex mine accident rate" by $20 \%$, then we can roughly assume that a $1 \%$ decrease in the "Complex mine accident rate indicator" at a coal mine costs one million hryvnia.

In addition, fine-tuning at a specific coal mine will require considerable time and additional costs before obtaining permission from the State Department of Industrial Safety, Labor Protection and Mining Supervision (Gosgorpromnadzor) (Лопатин, 2016). This is a strict requirement of clause 4 of the "Procedure for issuing permits by the State Committee for the Supervision of Labor Protection and its Territorial Authorities" of the Resolution of the Cabinet of Ministers of Ukraine No. 1631 of 15.10. 2003 and item 1 of Art. 20 of the Mining Law of Ukraine, No. 1127-XIV of 10/06/1999.

\section{CONCLUSIONS}

The "lifetime" of a regular computer model (UTAS basics) is about five years. And there are not only quantitative changes - speed, but also qualitative ones - new principles of organization, software and incompatibility with old models appear. Therefore, it is important at the UTAS project stage to lay down a new quality: a fundamentally new physical or methodical idea of controlling the production processes of coal mines, focusing on the equipment of tomorrow and a significant increase in the accuracy or range of parameters controlled by UTAS. Otherwise, UTAS will not be supported by new software, meet the trends and needs of tomorrow, as well as the possibility of adaptation and modernization.

\section{REFERENCES}

Aleksandr Khokhotva, 2014. Pravda i vymysly o «nou-khau» nashey strany/ Bseukrainskiy yezhemesyachnyy nauchno-tekhnicheskiy zhurnal «TEKHNOPOLIS». № 4(208), s. 15.

Aleksandr Khokhotva, Viktor Shaytan, 2014. UTAS: uverennyye shagi vpered/ Bseukrainskiy yezhemesyachnyy nauchno-tekhnicheskiy zhurnal «TEKHNOPOLIS». № 4(208), s. 16-18. 
Boris Gryadushchiy, 2012. Tyazhelyye plasty neponimaniya //Okhrana truda - № 5, s. 32-34.

Lopatin V.V., 2016. Obespecheniye neobkhodimoy tochnosti mobil'nykh sistem kontrolya $\vee$ gornoy i neftegazovoy otraslyakh/ Lopatin V. V. // Metodi ta priladi kontrolyu yakostí. Naukovo-tekhníchniy zhurnal - Ívano-Frankívs'k - № 2 (37), S. 5-13.

Lopatin V.V., 2017. Otzyv na stat'yu Nazimko V.V., Kolesnik N.A. Stokhasticheskiye osnovy marksheyderskogo obespecheniya bezopasnogo vedeniya gornykh rabot / Ugol' Ukrainy, 2014. - № 11// Zhurnal «Ugol' Ukrainy», № 5-6, S.69-71.

Materialy Ukrayins'koho mizhnarodnoho enerhetychnoho forumu, 2011. - Kyyiv, kviten' r. 47-54

$\mathrm{Na}$ shakhte vo L'vovskoy oblasty proyzoshel vzryv: mnoho pohybshykh https://24tv.ua/ru/na_shahte_vo_Ivovskoj_oblasti_vzorvalsja_metan_mnogo_po gibshih_n788447

$\mathrm{Na}$ shakhte ymeny Zasyad'ko $\mathrm{v}$ okkupyrovannom Donetske pohyb hornyak. https://antikor.com.ua/articles/174625-

na_shahte_imeni_zasjadjko_v_okkupirovannom_donetske_pogib_gornjak

Nikolay Nos, 2012. Ot absolyutnoy bezopasnosti k priyemlemomu risku//Okhrana truda. №6, S. 16-17.

Sistema bezopasnosti UTAS ustanovlena na 37 shakhtakh v Ukraine, Gosgorpromnadzor. https://112.ua/obshchestvo/sistema-bezopasnosti-utasustanovlena-na-37-shahtah-v-ukraine-gosgorpromnadzor-79111.html

Taisiya Zhelikhovskaya. Uverennyy start s nadezhnoy platformy, 2014. Bseukrainskiy yezhemesyachnyy nauchno-tekhnicheskiy zhurnal «TEKHNOPOLIS» № 5(209), S. 23-27.

Yuriy Sagan', 2012. Shakhte - vtoruyu zhizn'/Hauchno-proizvodstvennyy zhurnal «Okhrana truda» №5, S.35

\begin{abstract}
.
The analysis of the state of security in the coal mines of Ukraine showed an urgent need for equipment to monitor the safety of production processes, identifying its shortcomings. The necessary regulatory requirements of the legislation of Ukraine on this issue have been considered in detail. A solution to the problem of creating modern equipment for monitoring the safety of production processes in coal mines through a new approach and a change in concept has been proposed.
\end{abstract}

Keywords: safety, coal mines, production process, control equipment, acceptable risk 